enactinent, would be more likely to benefit the profession altimately, than a temporizing acceptance of the sinalle-t possible concession to well-considered dernands. - I am, gentlemen, your obedient servant,

Gloucester, March 4, 1811.

H. W. RuYser.

\section{THE MEDICAL CONPERENCE.}

\section{LETTER FROM DR. MACARTNEY.}

IO TEE EDITORS OF THE PROVIXCIAL MEDICAL AND SURGICAL JOUnNat.

Genthemen,-The delegates of the different medical associations, who lately met in London, having dope me the honour of appointing me their chairman, I feel particularly called upon to account for my secession from their meetings; for which purpose, it may perhaps be sufficient to send you the following copy of my letter to the secretary of the Conferétuce :-

"Pebruary 11, 1841.

"Srn, - I beg leave to inform you, that I do not propose to attend the future meetings of the delegates, now sitting for the consideration of medical reform, as I do riot think the delegates at present assembled represent the great b $\delta \mathrm{dy}$ of the profession, and as 1 do not approve of many parts of the plan of a bill submitted to their discuesion.

"It has always appeared to me, that if the medical corporations admit the representative principle in the constitution of their governing boards or councils, there is no necessity for the creation of any new medical faculty.

"I have the honotur to be,

$$
\text { "Your very obedient servant, }
$$

"Jaites Macartinet."

I did not send in my resignation to the council of the Provincial Medical and Surgical Association, by whom I had been appointed, (onbsequently to obtaining my consent to undertake the trust,) becanse I did not then know what steps the council of that association would take, or whether triy setrices might not in sotne other way be still required.

I think it necessary to add, that I did not withdraw from the conference, under any disappointed or piqued feeling, hávining beeti uniformly treated with marked kindness and respect by the aclegates, but altogether from $a$ sense of what I considered to be my public duty.

I am, Gentlemen, your obediont servant,

Southawpton, March 8, 1841. Jaues Macarteer.

\section{THE MEDICAL CONFERENCE.}

Te FHE EDTrow or THE PROVHCHAL MEDICAL AND SURGICAL JOURNAL.

Gentremen, - As a member of the Conference on the all-impo:tant subject of Medical Reform, having been so delegated by the Provincial Medical and Surgical Association, I feel called upon to state to your readers the exact circumstances under which that conference has been constituted, and the strict course by which its procecdings have been condricted. I am led to take this step, in consequence of the impression made by your leading articles of the bust two weeks, which appear to stamp the Conference with a character that it onght not to bear. 1 am quite satisfied that those papers have been written upon false infotmation-upon false data. I thus understand the Conference to have been formed of delegates from rarious societies, who were commissioned to inquire into the grievances under which the profession labonrs, and to frame such measures as might remedy those evils.

With this view members of the ditterent associations were appointed in the following order:-

\begin{tabular}{|c|c|c|}
\hline Irish & " & \\
\hline Gl & "6 & ... \\
\hline von & o6 & ..... \\
\hline & " & $\ldots$ \\
\hline Hasg & “ & 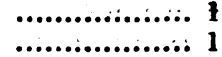 \\
\hline
\end{tabular}

$$
\begin{aligned}
& \text { British Medical Astociation.................. } 6 \\
& \text { Ptotiticial } \\
& \text { North of England } \quad \text { " ...................... } 1
\end{aligned}
$$

Thus it will be perceired that the original constitntion of the Conference yields a large proportion to provipcial delegates, and of the whole number (21) who attended the meetings, 13 were mumbers of the Provincial Association. It might occasionally have happened in the Conference that a provincial member would be outroted; and such has occurred to myself with one of my colleagues, but our votes and protest upon that particular point have been recorded and noticed. On these grounds, gentlemen, I feel that you are not rightly inforned, when you represent the constitution of the Conference as unfair. But 1 now come to the second point, namely, "that its proceedings have been of such a character as to entitle it to the animadversion of the profession." So far as the proceedings have hitherto gone they have been confined simply io the est $x$ blishment of leading principles of reform - which principles having been agreed to by the Conference, have been submitted to the Colleges of Physicians, of Surgeons, and the Apothecaries' Company. 'The principles were partly elicited by the reading of a schene of reform adopled by the British Assocjation, and indeed most ably drawn up, I believe by Dr. Webster; but no bill has been concocled as yet by the Conference, embodying the principles laid down.

I think the charge of secriecy in the business of the Conference is also unfairly stated. I was one who roted against the putlication of the proceedings of the Conference until they could assume such a form as to be fitted for the eye of the profession, and thereby convey a correct idea of the actual opinions of the Conference; and I think I am still right in the vote I then gave. It was intended to prevent piecemeal publication in a garbled form. The principles on which the Conference would ground any legislative measures are noso before the profession, and it is open to the profession at large, and it would be well if they did convey to the Conference their opinions an those leading principles of reform. I am quite sure that the Conference would freely listen and attend to such representations; for, as far as I lave yet seen, there is an unanimous wish to benefit the profession and the public at large; and this spirit has pervaded their transactions throughout.-I have the honour to be, gentlemen, your obedient servant,

Winchesler, March 3, 1841.

\section{NEWCASTLE SPRING ASSIZES. Thursday, March 4.}

TORBOCK V. LAING, SCOTT, AND HORN.

$A$ cavse, of much interest to the profession, was decided in favour of a medical gentleman at this assizes. The circumstances of the cise, which we abridge from the last number of the Gateshead Observer, are brief $y$ as follows:-

Mr. Alexander stated the case. The plaintiff was Mr. Thomas Reddish 'Torbock, a highly respectable surgeon in Sunderland, and his claim arose out of the following circumstances :- In January, 1840, Jane Sparrow, an aged widow, was passing along Sunderland bridge, when tho defeudants were blisting stone, and a great piece of the stone was thrown over the ruiling, and shattered her arm a little above the wrist. She was cunducted by a passer-by to the plaintiff's surgery, where she received every proper attention. The plaintiff called in Mr. Matin, a brother surgeon, to his assistance, and it was thought at first that amputation would be necessary. This, howevery wat avoided, and, through the attention and still of the plaintiff, the poor woman was at length restored to nearly her former state. Within forty-eight hqurs of the accident, 
a gentleman called from the Ayre's Quay Bottle Company, and requested Mr. Torbock to spare no pains for her recovery, and they would bear all expenses. The attendance of the plaintiff was required for about four months; and some time after her restoration to health, he made out his bill. At the professional rate of charges, the anount exceeded 50l.; but the plaintiff, taking into consileration all the circumstances of the case, struck off $10 l$., and sent in a bill for $40 l$. $5 s$. The defendants, however, objected to the sum charged, and proposed a reference. The plaintiff at once acceded to the proposal, and referees were uppointed; but they could not come to an agreement, and the plaintiff was compelled to seek redress in a court of law. The defendants seemed to think, that the plaintiff ought to have sent them such a bill as he would have presented to the poor woman herself, had the payment of the charge devolved upon her. This was obviously absurd. The injury was caused by the defendants, and it was only fuir that the bill should be made out according to their station in life, and not with reference to the poverty of the aged widow. The plaintiff, with a commendable spirit, had made a very handsome deduction, in consideration of the sacrifice which the defendants were called upon to make; but with this they were not satisfied, and he had very properly resisted their attempt to deprive him of the fair ramuneration of his skill and attention.

The particulars of the case, as stated by the learned counsel, having been established by several witnesses, Mr. John Croudace and Mr. Edward Malin proved that the charge was reasonable one, and that the medicines and attendances were all required.

The defence set up by Mr. Dundas for Messrs. I aing \& Co. was, that the charge was exorbitant, and that the angeon's bill should have been made out with reference to the humble condition of the poor patient, and not to that of the defendants.

In support of this theory, Mr. George Green, of Sunderland, Mr. William Green, of Durhan, Mr. W.J. Dodd, of Monkwearmouth, and Mr. William Mordey, of Sunderland, were ealled to demonstrate the exorbitant nature of the charge; these gentlemen would have thought from ten to twenty pounds amply sufficient remuneration.

The learnod judge, (Baron Rolfe,) in his address to the jury, observed, that there existed an anomalous state of things in the medical profession-a system of charging difforent rates to the rich and the poor, the rich making come atomement to medical gentlemen for the sacrifice which they made in their attendance on the poor. This mas, in many respects, a beneficial state of things; and it raied a question for the jury in this case, viz. whether the bill of the plaintiff ought to be regulated by the high or the low acale of cliarges. The defendants had requested the plaintiff to attend upon the poor woman-and to bestow every possible attention upon the case. They had made themselves liable to payment of the bill; and the jury were to decide whether the charge ought to be regulated by the circumstances of the defendants or the patient. If the furmer, the weight of evidence, he thought, went to show that the sum paid into court was not sufficient; if the latter, then it seemed to him that it ought to suffice.

Vendict for the plaintiff for $40 l .5 s$.

\section{SHR ASTLEY COOPER, BART. F.R.S.}

TO THE EDITORs OF THE PROVINCIAL MEDIC.IL AND GURGICAL JOURNAL.

Gentrenen,-Many inquiries having been made as to the appearance of a "Life of Sir Astley Cooper," I beg to inform you, for the information of the professio:, that this dietimgusused surgeon has left ample materials for a most intoreating biography, now in the hands of his nephew, Bransby Coeper, Esq. by whom the whole will be arranged and prepaned for speedy publication.

A ners edition of his beautifully illustrated work on the
"Testis," which received the author's final additions, has passed through the press. 'The plates are now in process of colouring, and the volume will be issued during the present inonth.

His work on "Dislocations" I am now preparing to publish of an octavo size, with the plates re-drawn, engraved on wood in the best style, and printed with the text, carefully edited, with additions, by B. Cooper, Esq. This practical work will be offered at a price to make it available to every student of surgery. - I am, your obedient servant, John Churchile.

Prince's-street, Solıo, March 1st, 1841.

\section{HOUSE OF COMMONS, Marca 8.}

$$
\text { NEW POOR-LAW BILL. }
$$

Mr. WAKLEY, after some observations on the proposed alterations of Lord John Russell, asked the noble lord whether it was his intention to make any change with respect to the medical department under the bill $\mathrm{He}$ was aware that several deputations of medical men had ivaited on the noble lord, and that several very important suggestious as to the best mode of medical attendance and treatment in unions had been made, and he hoped that as he was then about to remodel the bill, he would introduee and give his sanction to some of those salutary medical improvements which had been suggested.

Lord Johs Ressect replied, that it had been found that great improvements had been already made in the medical department, under the authority and inspection of the guardians; and he thought it would be much better to leave it under such improving care, than to make it the subject of special legislative enactment.

\section{ROYAL COLLEGE OF SURGEONS IN LONDON.}

Aт a meeting of the council, on Wednesday, the $3 d$ instant, Benjamin Travers, Esq. was elected an examiner, and John Flint South, Esq., (both of St.Thomas's Hospital, ) a member of the council, in the vacancies occasioned by the lamented decease of Sir Astley Paston Cooper, Bart.

\section{LIST OF GENTLEMEN ADHITTED NENBERS,} On Friday, Nurch 5, 1811.

John Wheatley Hiron, Smith Hobson, George Thumas Vicary, Raymond Levi Haynes, Juhn Spencer, Charles Colvilic Turner, Henry James Penny, Frederick Wright, William 'lodd White, John Buck Stedman, John Graj; Wa'ter Rice Howell Harker, Edward Brunker Thring, Richard Yaul.

DROVINCIAL: MEDICAL AND SURGICAL JOURNAL, Edited by Dr. Heswis GREEN (London), and Dr. STREETEN ( $W$ orcester).

At a late branch-meeting of the Provincial Medical and Surgical Association at Bridgewater, it was unanimously resolved, “- That the meeting take this opportunity of strongly stating their satisfaction that the Fro vincial Medical axp Surgical Joursal has been established, aud pledge themselres to give their cordial support to the Editors in their laudable undertakin."

The chief objects of the Jourxa $\mathrm{L}$ are-lst, To represent in an adcquate manner, Medical Science in the Provinces. 2d. To serve as an organ of communicatiou between the members of the difterent Association througliout the Kingdom. The Joursal (being stamped) can be for warded $b y$ post to any part of the British doninious. TERMS OF SUBSCRIPTION :

One Year, 12. 10s.-Six Mouths,-15s.-Singlt Number, 6d. (Slamped, id.) Single numbers may be obtained troin any Bookseller or Newsman. To be had also of the Publishers, Messrs. William Ball and Co. Paternoster.row.

N.B. A post-office order, for six or twelve months, can be obtained at any post-othice.

Printed dy Ricuard Cray, of No. 5, Nermatrket Terrace, Cambrilge Heath, in the County of Middlesex, at his Printing-oflice, Nos. $i$ and 8 ; Bread-street Hill, in the Parish of St. Nicholas Olave, in the City of London; and published by WILLIa a BaLL, of No. 34, Paternoster Row: in the City of Lo:den, at No. 34, Paternoster Row. - Saturday, March 1: ist1. 